\title{
ROLE OF TRANSFORMATIONAL LEADERSHIP AND TRANSACTIONAL LEADERSHIP ON ORGANIZATION INNOVATION
}

\author{
Dr. Ploychompoo Kittikunchotiwut ${ }^{1}$ \\ ${ }^{1}$ Mahasarakham Business School, Mahasarakham University, Thailand \\ Ploychompoo.k@acc.msu.ac.th, 66804657878
}

\begin{abstract}
This study investigates the mediating effect of entrepreneurial orientation on the relationship between transformational leadership, transactional leadership, and organization innovation. The data were collected by using a questionnaire from 135 software industry in Thailand. We use structural equations modeling (SEM) to explore the mediating effect of entrepreneurial orientation on a positive relationship between transformational leadership, and organization innovation directly and indirectly through the construct. The mediating effect of entrepreneurial orientation on a positive relationship between transactional leadership, and organization innovation directly and indirectly through the construct.
\end{abstract}

\section{Keywords}

Transformational Leadership, Transactional Leadership, Entrepreneurial Orientation, Organization Innovation

\section{JEL Classification}

L16, L26

DOI: https://doi.org/10.14311/bit.2019.02.01

Editorial information: journal Business \& IT, ISSN 2570-7434, CreativeCommons license (c) (i) published by CTU in Prague, 2019, http://bit.fsv.cvut.cz/ 


\section{Introduction}

It has been widely acknowledged that in today's world, a company has to continually explore new business prospects. Dess, Lumpkin, and McGee (1985) argue, "Virtually all organizations- new startups, major corporations and alliances among global partners - are striving to exploit product market opportunities through innovative and proactive behavior." Behaving entrepreneurially is crucial in order to thrive ( $D^{\prime}$ Intino et al., 2007). In other words organizations require inventiveness and originality as well as dedication and enthusiasm. As a result of this need, it follows reason that research and development in the area of entrepreneurial behavior has increased dramatically. Specialists desire to identify the organizational and environmental factors involved in entrepreneurial behavior. Energizing people, demonstrating entrepreneurial creativity, seeking out new prospects, engaging in new opportunities, risk taking, exploring new ventures, and inspiring other people are some of the factors that could be of primary importance (Bremer, 2009). Out of all of these factors, it could be argued that leadership is the most important entrepreneurial behavior.

Leadership is a relatively new idea that has become of utmost importance to businesses ranging from small, local stores to global corporations. Leadership provides a way to study the interaction between people and their environment; especially when looking at the entrepreneurial orientation ( $D^{\prime}$ Intino et al., 2007). In Thailand, it is a society in which inequalities are accepted; a strict chain of command and protocol are observed. Each rank has its privileges and employees show loyalty, respect and deference for their superiors in return for protection and guidance. This may lead to paternalistic management. Thus, the attitude towards managers are more formal, the information flow is hierarchical and controlled. Moreover, this is manifest in a close long-term commitment to the member 'group' (a family, extended family, or extended relationships). Loyalty to the in-group in a collectivist culture is paramount, and over-rides most other societal rules and regulations. The society raises strong relationships where everyone takes responsibility for fellow members of their group. In order to preserve the in-group, Thai are not confrontational and in there communication a "Yes" may not mean an acceptance or agreement. An offence leads to loss of face and Thai are very sensitive not to feel shamed in front of their group. Personal relationship is key to leading business and it takes time to build such relations thus patience is necessary as well as not openly discuss business on first occasions (Geert Hofstede, 2001). Additionally, Thailand has the lowest Masculinity ranking among the average Asian countries of 53 and the World average of 50 . This lower level is indicative of a society with less assertiveness and competitiveness, as related to one where these values are considered more important and significant. This situation also reinforces more traditional male and female roles within the population. Furthermore, Thailand's low score of 32 indicates that Thai culture is more normative than pragmatic. People in such societies have a strong concern with establishing the complete Truth; they are normative in their thinking. They exhibit great respect for traditions, a relatively small partiality to save for the future, and a focus on achieving quick results (Geert Hofstede et al., 2010).

Leadership gives a significant advantage in the competitive market that businesses face and often leads directly to organizational innovation (Samad,2011; Tellis, Prabhu, Chandy; 2009). In order to achieve these objectives, the human factor is of utmost importance. The leader, whether it be a CEO, CFO, or simply a manager, must be able to guide the members (or human factor) of the organization in such a way that efficiency is maximized in order to achieve the predetermined goals and objectives. The definition of 'leadership' has been used to describe people in terms of their ability, personality, level of responsibility, influence, behaviour, or their instruments to achieve a goal (Limsila and Ogunlana, 2007). Leadership is allowing employees to thrive in the company by assigning them to a task which most closely suits their abilities. It is also having the ability to keep those same employees motivated over a period of time (Kotter,1996; Yammarino and Dubinsky, 1994). Leadership provides an important aspect to the relationship between an individual and the organization. The individuals that make up various 
groups in the organization must behave as the leader determines or dictates (Shastri, Shashi Mishra and Sinha, 2010). A leader has the ability to direct the actions of his followers by way of different management methods. The predominant leadership styles of transformational and transactional leadership have been researched extensively over recent years. However, there has been no research exploring the relationship between transformational, transactional leadership, entrepreneurial orientation, and organization innovation. Therefore, this study's goal is to bridge the gaps of previous research.

The purpose of this paper is to tackle the above limitation by examining how the composition of transformational and transactional leadership affects the entrepreneurial orientation, entrepreneurial orientation affects the organization innovation, which in turn affects the transformational and transactional leadership directly and indirectly affects the organizational innovation.

\section{Literature Review}

\section{Transformational Leadership and Entrepreneurial Orientation of Software Industry}

Transformational leadership can be construed as the mechanism that both influences major changes and enhances the duty of care that members display towards an organizations goals and intentions. This is achieved through a change in the mindset and presumptions of organizational members Chelladurai (2001). A transformational (extraordinary) leader heightens follower's levels of awareness with regard to the significance and monetary worth of the potential results and the methods that are needed to achieve them. As well as this, they are responsible for promoting the self-drive of their followers, which will, as results allow the said followers to demonstrate their own immediate preoccupation for the advancement of the organizations goals and aspirations. Four specific factors were outlined by Bass (1985) with regard to transformational leadership. The author suggested that charisma, inspiration, individualized consideration and intellectual stimulation were all key to the framework. Leaders who act as role models demonstrate charisma. This, in turn can produce a shared feeling of recognition of a shared goal. In addition to this, charisma can be said to inject a sense of pride and belief in followers by prevailing through obstacles and hindrances. The author proposes that it is possible to label transformational leadership as 'idealized influence '. It is also suggested that this can then be extended into two sub-dimensions known as 'idealized influence attributed' and 'idealized influence behavior'. The inspiration and empowerment of follower's refers to inspiration. When followers have inspiration, they are more likely to willingly accept and take on a potentially difficult mission or goal. The consideration of individuals applies to behaviors such as exhibiting personal respect to followers; this is achieved by showing them personal consideration, by treating each person as an individual, and by being attentive to individuals personal requirements. Finally, leaders who demonstrate contemporary ways in the consideration of old obstacles, communicate this new way of thinking clearly, and aim to make followers think again about their usual procedures and theories can be described as being intellectually stimulating. In addition to the above, transformational leadership can be described as a leader's capacity to evaluate his or her followers' requisites, necessities, and personal drive, as well as their competency in assessing the higher-level demands of their employees, and in doing so exposing the full potential of the respective follower. The results of transformational leadership are behavioral patterns that differ from those displayed by transactional leaders, these behavioral patterns can be said to induce a positive change within organizations (Bennis,1980; Conger 1989; Conger and Kanugo; 1987; Sashkin; 1990). In this study, we use Sashkin and Rosenbach's (1998) definition of transformational leadership. The authors have utilized extensive leadership research data, with special consideration of the work of Bennis (1984), and have formulated the Visionary Leadership Theory, a comprehensive, all inclusive take on leadership. Sashkin and Rosenbach (1998) attempted to interpret transactional and transformational leadership dimensions through their Visionary Leadership 
Theory as: substituting when necessary, building trust worthy relationships, showing empathy, creating opportunities for empowerment and improving self-confidence, and visualization of positive leadership characteristics. In the Sashkin and Rosenbach (1998) approach of Visionary Leadership, vision is concerned with the capacity to first thoughtfully construct the future, followed by physically doing so through behavior. This is displayed by leaders when they carefully consider what is happening in a given situation, anticipating and identifying the causes, in doing this, they are able to widely understand how intricate patterns of cause and effect come to light. This is the moment when a leader can theorize how to extract desired outcomes. It is not the intention of visionary leaders to simply postulate a vision and force it onto their followers. The idea of vision runs parallel with the intentions of the organization, meaning that the leader can produce a clear and transparent vision and relate it to their staff, which, in turn, will permit the organization to be more dedicated, innovative, contemporary and more risktaking. In this article, we suggest that CEO's who display leadership behavior such as those described by Sashkin and Rosenbach (1998) are likely to have a beneficial entrepreneurial strategic posture.

\section{Transactional Leadership and Entrepreneurial Orientation of Software Industry}

Transactional leadership can be defined as a way in which a leader uses a reward system (which is often currency based in nature) to entice followers into action. This style centers on maintaining functionality in the short term by working to change actions reduced administration. These behaviors revolve around making sure that those following the leaders understand what is being asked of them, have the ability to do what they are asked, as well as ensuring that the individuals have the resources needed to accomplish their goals (Rosenbach, Sashkin, and Herberg, 1996). Bass (1985) describes a transactional leader as "one who operates within the existing system or culture, has a preference for risk avoidance, pays attention to time constraints and efficiency, and generally prefers process over substance as a means for maintaining control." That being said, transactional leadership is, at heart, a transaction between leaders and followers. The followers are expected to offer progress and accomplishment of specific goals. In return, the leader will monitor their headway and identify what rewards are deserved when a task is completed. There is an expected increase in followers' compliance to the leader through these types of exchanges (Yukl, 1998).

Transactional leadership encompasses two discernable factors related to behavior. These factors are contingent reward and management by exception. Contingent reward gives positive reinforcement to the followers when a goal is met or a contract is completed and is known as a motivation-based system. Management by exception is a process in which the leader does not intervene (and may not even be notified) unless there is a problem which cannot be solved by the followers themselves. As long as the methods that are employed currently function properly and the previously set goals are achieved, the status quo is maintained. Management by exception can also be divided into two sub-groups: active components and passive components. Active management by exception is defined as a management variety involving watching intently for mistakes while passive management by exception refers to a leader who waits to hear about these mistakes either from the followers themselves or from the goals not being met. In both instances, the leader will punish the followers involved in the event that the follow does not meet the standards of performance (Antonakis, Avolio, and Sivasubramaniam, 2003).

Literature on entrepreneurship has widely acknowledged the importance of transactional leadership to entrepreneurial orientation (Zahra et al., 1995; Wiklund, et al., 2004; Covin et al., 2006). According to Covin and Slevin (1989) entrepreneurial orientation is the "methods, practices, and decision-making styles that managers use to act entrepreneurially." Lumpkin and Dess (1966) went a step farther and characterized entrepreneurial orientation by five dimensions, four of which will be looked at in this piece: innovativeness, risk taking, proactiveness, and competitive aggressiveness. 
Innovation, the first dimension, indicates a company's ability to support and employ novel concepts. This adaptability and openness to novelty, experimentation, as well as the creative process allows innovative goods, services, or technology-related techniques to emerge (Lumpkin and Dess, 1966). Innovation is especially vital for organizations working with new and changing technology, such as software. Software industries bear a high level of uncertainty when compared to more traditional industries because they face short life cycles for their products, which are easily discarded to be replaced by the newest and best software (Baron et al., 1999; Vohora, Wright, and Lockett, 2004). This innovation is essential in order to create a better technology and a higher turnover rate. The organizations which utilize innovation to its full extent are more likely to take advantage of market opportunities (Wiklund and Shepherd, 2005). Innovation can help software industries develop competitive advantages and design the necessary sdproducts and resources to stay relevant in an everchanging market.

The second dimension of entrepreneurial orientation spoken of by Dess and Lumpkin is risk taking. Risk taking is the extent to which managers will make large and risky resource commitments (Miller and Friesen, 1978). With its technology changing so quickly, software industries face more risks and a more uncertain future than many traditional industries. Risk taking may cause deficits in the short run, but can create opportunities in the future. This can have a positive impact on performance (Dess and Lumpkin, 2005). Because of this, risk taking is likely to pay off for organizations that need to change as often as software corporations do.

Proactiveness is the third dimension of entrepreneurial orientation. This is again using the example of the software industry, technological firms need to think ahead in their actions and ensure that they maintain an advantage over their competitors in a market that changes at a daily rate (Cottrell and Sick, 2002). Proactive companies can acquire higher profits and establish a reputation as a leader in their field (Porter, 1980). Being known as the most competent company in the latest technologies will increase overall market approval. Development of advanced production processes can also lead to a predominant performance in the market; another benefit of proactiveness.

The fourth dimension of entrepreneurial orientation, and the final dimension as far as our paper is concerned, is competitive aggression. Aggression is a crucial factor in the unquestionably competitive environment that is the current global market. As a dimension of entrepreneurial orientation, aggressiveness in this case is defined as a corporation's inclination to engage in the competitive market in order to meet pre-arranged goals or lead to an increase in their current position. Aggressive behavior must be direct and must intensely challenge the organization's competitors in the landscape they are both involved in (Lumpkin and Dess, 1996). New technologies and products of any industry, but especially those of software companies, can be learnt and duplicated almost instantaneously by competitors (Dess and Lumpkin, 2005). It is imperative that companies set ambitious goals and frequently redefine their products and services in order to build strategic barriers against their opponents. Aggressive activities help outperform competitors.

\section{Entrepreneurial Orientation and Organization Innovation of Software Industry}

As previously mentioned, entrepreneurial orientation focuses on the process of making strategies for the betterment of an organization. We conceive entrepreneurial orientation similarly to how Covin and Slevin, (1989) did; that is to say, we conceive entrepreneurial orientation as a managerial inclination that guides the process in making strategies after an entrepreneurial and strategic disposition. There are comprehensive studies which promote the idea of a decisive link concerning the interconnection of entrepreneurial orientation and an organization's performance (Baker and Sinkula 2009; Rauch et al., 2009; Sadler-Smith et al., 2003; Wiklund, 1999). We propose that entrepreneurial orientation affects organizational innovation. 
Furthermore, there is a connection to literature involving strategic management. Management choices made with a positive entrepreneurial orientation could explain the transmission of organization aptitude within an organization (Zott, 2003). Entrepreneurial orientation leading to organizational innovation could be instrumental in explaining why some companies perform better than others; despite all other aspects appearing to be equal (Zott , 2003). Additionally, organizational innovation might further the idea that entrepreneurial orientation effects organizational innovation because it signifies that the entrepreneurial stance is leading to an effect in the firm or that the firm is behaving in a manner which can only be described as entrepreneurial, because of the determinations of the management.

A number of authors have contended that entrepreneurial behaviors are having straightforward consequences on goods, techniques, and managerial ingenuity. Although studies have generally thought of ingenuitous results as an index of entrepreneurship, it has become clear that this exchange is in dire need of an increased examination. As previously stated, entrepreneurial orientation increases risk taking behaviors, innovation, and proactiveness within an organization (Zahra, Nielsen, and Bogner, 1999). Thus, entrepreneurial orientation can be determined to be one of the precedents to organizational innovation (Renko, Carsrud, and Brännback, 2009).

The organizational innovation of an industry includes innovations of products and processes. The aforementioned types of innovation are scrupulously associated and the process of innovation generally involves all company functions (Utterback and Abernathy, 1975). Because of this, we can describe product innovation as how a good or service can be modified. This application focuses on the needs of the customer or the market while process innovation differs completely because it is described as how a modernity of the production process can change the technique or employee actions in order to increase efficiency within the company (Damanpour and Gopalakrishnan, 2001). Because of the evolvement of the emulous market, innovation is critical for company performance (Wheel wright and Clark, 1992). It is essential to modernize regularly in order to achieve positive and longlasting developments in an organization. These results must be extensively noticed between the company. It is important to note that this theory has been researched to a broad extent and has been mentioned in this research multiple times.

\section{Method}

\section{Sample and data collection}

Processes related to organizationa innovation, as well as outcome of those processes. For this reason, we tested our hypotheses by focusing on a single industry in Thailand. Carrying out a single-industry analysis is also interesting because it facilitates the identification and measurement of critical resources in an industry (Hitt, Bierman, Shimizu, and Kochlar, 2001). Therefore, this study selected software industry in Thailand as the sample. Additionally, because our target population is relatively homogeneous, we control to a certain extent for size, industry, and national culture contingency factors (Lyon, Lumpkin, and Dess 2000; Rauch et al., 2009). The population was obtained from a list database of software industry in Thailand as of February 20, 2018 (http://www.atsi.or.th). A mail survey procedure via questionnaire was used for data collection. The key participants in this study were executives or managers. With regard to the questionnaire mailing, 15 surveys were undeliverable because some firms were no longer in business or had moved to unknown locations. Deducting the undeliverable from the original 525 mailed, the valid mailing was 510 surveys, from which 140 responses were received. Of the surveys completed and returned, only 135 were usable. The effective response rate was approximately $26.47 \%$. According to Aaker, Kumar and Day (2001), the response rate for a mail survey, without an appropriate follow-up procedure, and greater than $20 \%$, is considered acceptable. 
Furthermore, a non-response bias test was performed by comparing early and late responses. Characteristics of the firms comprise industry types, amount of capital funding, time in business, number of employees, and key informants who self-reported all constructs (Armstrong and Overton, 1977). As for non-response bias, t-test statistical tests were performed and; the results exhibited no significant differences. Therefore, a non-response bias is of no concern in this data.

\section{Measurements}

The survey instrument is a multi-item measures. All the variables were measured using five-point Likert scales. The key informants were asked for the levels of agreement with statements of items ranging from 1 (strongly disagree) to 5 (strongly agree). The items were developed from existing scales of each variable for this study specifically.

\section{Transformational Leadership and Transactional Leadership}

In this research we used twenty factors from the Turkish version of the Multi-Factor Leadership Questionnaire (MLQ-Form 5X) to assess transformational leadership and transactional leadership (Bass and Avolio, 1995). Avolio et al., (1999) contribute to the question of the validity of the instrument. If participants provided both the transformational leadership ratings and the criterion ratings, the results could have potentially been biased by same-source (MLQ) data. Therefore, only the transformational leadership items were used from the questionnaire. Participants judged how frequently their immediate leader engaged in transformational leadership behaviors. Ratings were completed on a 5point scale with 1 representing "Not at all" and 5 representing "Frequently, if not always". Sample items included: "Articulates a compelling vision of the future," "Treats me as an individual rather than as a member of the group," and "Gets me to look at problems from many different angles."

\section{Entrepreneurial Orientation}

Entrepreneurial orientation was measured with the widely used nine-item, 5-point scale proposed by Covin and Slevin (1989). This measurement scale has been applied satisfactorily by a number of empirical papers (Escriba' -Esteve et al., 2008; Green, Covin, and Slevin, 2008).

\section{Organization Innovation}

We consider organization innovation as a construct with three different dimensions consistent with the previous literature: product and process innovation effectiveness, and innovation efficiency. These dimensions have been generally discussed in innovation research (Brown and Eisenhardt, 1995; OECD, 2005). The OECD Oslo Manual provides a detailed measurement scale for assessing the economic objectives of product and process innovation, and we propose this scale to measure product and process innovation effectiveness. This scale was devised by the OECD to provide some coherent drivers for innovation studies, thereby achieving greater homogeneity and comparability among innovation studies. Nowadays, many innovation surveys use this widely validated scale (Alegre, Lapiedra, and Chiva, 2006; INE, 2008). Innovation efficiency is the third dimension considered to measure organizational innovation. It is generally accepted that innovation efficiency can be determined by the cost and the time involved in the innovation project (Brown \& Eisenhardt, 1995; Chiesa, Coughlan, and Voss, 1996; Wheelwright and Clark, 1992). 


\section{Control Variables}

The control variables were firm age and firm size. Firm age was measured by number of years firm has been in an operation. Firm size was measured by the number of employees in firms currently registered full time. Previous research has shown that the both control variables may influence the capacity of a firm to operate business in order to achieve performance (Zhou and Li, 2007).

\section{Analyses}

Structural equations modeling (SEM) were used to perform the primary analyses of the data set. SEM has been developed in a number of academic disciplines to Resource-Based View. SEM allows for the inclusion of latent variables that can only be measured through observable indicators. In this study, concepts such as transformational leadership and transactional leadership, entrepreneurial orientation, and organizational innovation are difficult to observe. Furthermore, SEM assesses measurement errors and allows all the relationships proposed in the conceptual model to be estimated simultaneously (Bou-Llusar, Escrig-Tena, Roca-Puig, and Beltra'n-Martı́n, 2009; Hair, Anderson, Tatham, and Black, 1998). EQS 6.1 software was used to estimate the models for our research hypotheses.

\section{Psychometric properties of measurement scales}

The psychometric properties of the measurement scales were assessed in accordance with accepted practices (Tippins and Sohi, 2003), and included Cronbach's alpha coefficient was used to evaluate the measurement of reliability. In the scale, Cronbach's alpha coefficients are higher than 0.70 (Nunnally and Berstein, 1994).Therefore, scales of all measures are shown to result in consistency. So, these measures are considered appropriate for further analysis because they show that validity and reliability that have be recognized in this study. The result shows factor loadings and the Cronbach's alpha coefficient for multiple item scales used this study in Table 1. Table 1 shows the all variables that have factor loading scores as between $0.658-0.935$. Additionally, Cronbach's alpha for all variables are shown between $0.749-0.904$. Therefore, all constructs of the validity and reliability of measurement can be applied for further analysis.

Table 1

Results of Measure Validation

\begin{tabular}{|c|c|c|}
\hline Items & $\begin{array}{c}\text { Factor } \\
\text { Loadings }\end{array}$ & $\begin{array}{c}\text { Cronbach's } \\
\text { Alpha }\end{array}$ \\
\hline Transformational Leadership (TL) & $0.658-0.865$ & 0.797 \\
\hline Transactional Leadership (TS) & $0.768-0.935$ & 0.904 \\
\hline Entrepreneurial Orientation (EO) & $0.757-0.883$ & 0.749 \\
\hline Organization Innovation (OI) & $0.722-0.873$ & 0.763 \\
\hline
\end{tabular}

Table 2 shows the factor correlations, means, and standard deviations for all variables. With respect to the possible problems relating to multicollinearity among independent variables, variance inflation factors (VIFs) range from 1.00 to 2.89 which was below the cut-off value of 10 as recommended by Neter, William and Michael (1985), meaning the independent variables are not correlated with each other. Therefore, there are no substantial multicolinearity problems encountered in this study. 
Table 2

Factor Correlations, Means, and Standard Deviations

\begin{tabular}{|c|c|c|c|c|c|c|}
\hline Variables & $\mathrm{TL}$ & TS & EO & OI & FA & FS \\
\hline Mean & 4.125 & 3.614 & 4.192 & 4.244 & 3.088 & 2.814 \\
\hline S.D. & 0.776 & 1.036 & 0.727 & 0.796 & 1.142 & 1.344 \\
\hline TL & 1 & & & & & \\
\hline TS & 0.146 & 1 & & & & \\
\hline EO & 0.236 & $0.181^{*}$ & 1 & & & \\
\hline $\mathrm{OL}$ & $0.203^{*}$ & 0.012 & $0.523 * *$ & 1 & & \\
\hline OI & $0.385^{*}$ & 0.211 & $0.555^{*}$ & $0.377^{* *}$ & 1 & \\
\hline FA & 0.046 & 0.010 & 0.006 & 0.016 & $0.169 *$ & \\
\hline FS & 0.158 & 0.007 & 0.052 & 0.029 & 0.152 & 1 \\
\hline
\end{tabular}

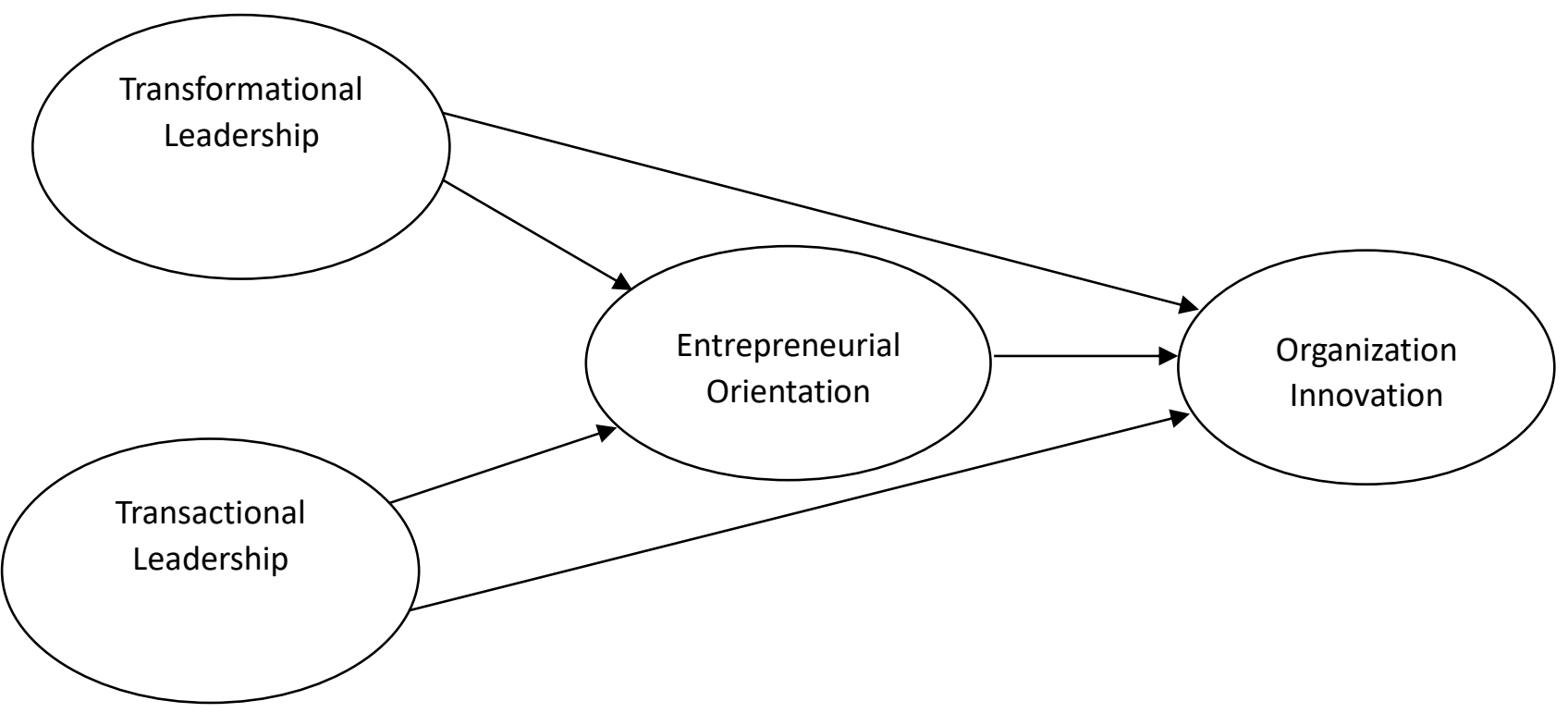

Fig 1 Hypothesized model

Fig 1 presents the theoretical model. The findings give the hypotheses concrete form. The study uses a recursive non-saturated model. Structural equation modeling takes into account errors in measurement, variables with multiple indicators and multiple-group comparisons (Koufteros et al., 2009).

\section{Results and Discussion}

The psychometric properties of the measurement scales were assessed in accordance with accepted practices (Gerbing and Anderson 1988; Tippins and Sohi 2003) included content validity, reliability, discriminant validity, convergent validity, scale dimensionality. Content validity was established through a revision of extant literature through personal interviews with ceramic tile industry experts (four 
ALICER technicians). We computed the coefficient alpha, composite reliability indicator to assess scale reliability (Bou- Llusar et al., 2009; Fornell and Larker., 1981). All scales achieved acceptable coefficient alphas, composite reliability indicators of at least 0.70 .

Discriminant validity was assessed through confirmatory factor analysis (CFA) by comparing the $x^{2}$ differences between a constrained confirmatory factor model with an interfactor correlation set to 1 (indicating they are the same construct) and an unconstrained model with an interfactor correlation set free. All $x^{2}$ differences were found to be significant, providing evidence of discriminant validity (Gerbing and Anderson 1988; Gatignon et al., 2002; Tippins and Sohi 2003). CFA was also used to establish convergent validity by confirming that all scale items loaded significantly on their construct factors (Gerbing and Anderson, 1988). All $\mathrm{x}^{2}$ differences were found to be significant, providing evidence of convergent validity (Gatignon et al., 2002).

We checked the constructs' dimensionality through the loadings of the measurement items on the first-order factors, and the loadings of the first-order factors on the second order factors. All loadings were above 0.40 and significant at $p<0.001$. No cross-loadings appeared. Before testing our hypotheses, we assessed the extent of common method variance by conducting a Harman's singlefactor test (Podsakoff et al., 2003; Podsakoff and Organ, 1986). This is a problem that can arise when dependent and independent variables are collected from a single informant. However, transformational, transactional leadership, entrepreneurial orientation, and organization innovation were asked to the same respondent: the general manager of the firm. The results of the CFA with all the indicators loading into a single factor ( $C F I=0.941, \mathrm{TLI}=0.920, \mathrm{GFI}=0.882, \mathrm{RMSEA}=0.074, \mathrm{CMIN} / \mathrm{DF}$ $=1.742, x 2=172.406,100 \mathrm{df}$ ) showed a fit, suggesting that the single-factor possibility is not relevant (Bou-Llusar et al., 2009).

Figure 2 shows the results of structural equations analysis. We carried out analysis including all the items and all the dimensions described in the measurements section. The chi-square statistic for the model is significant, but other relevant fit indices suggest a good overall fit (Tippins and Sohi, 2003).

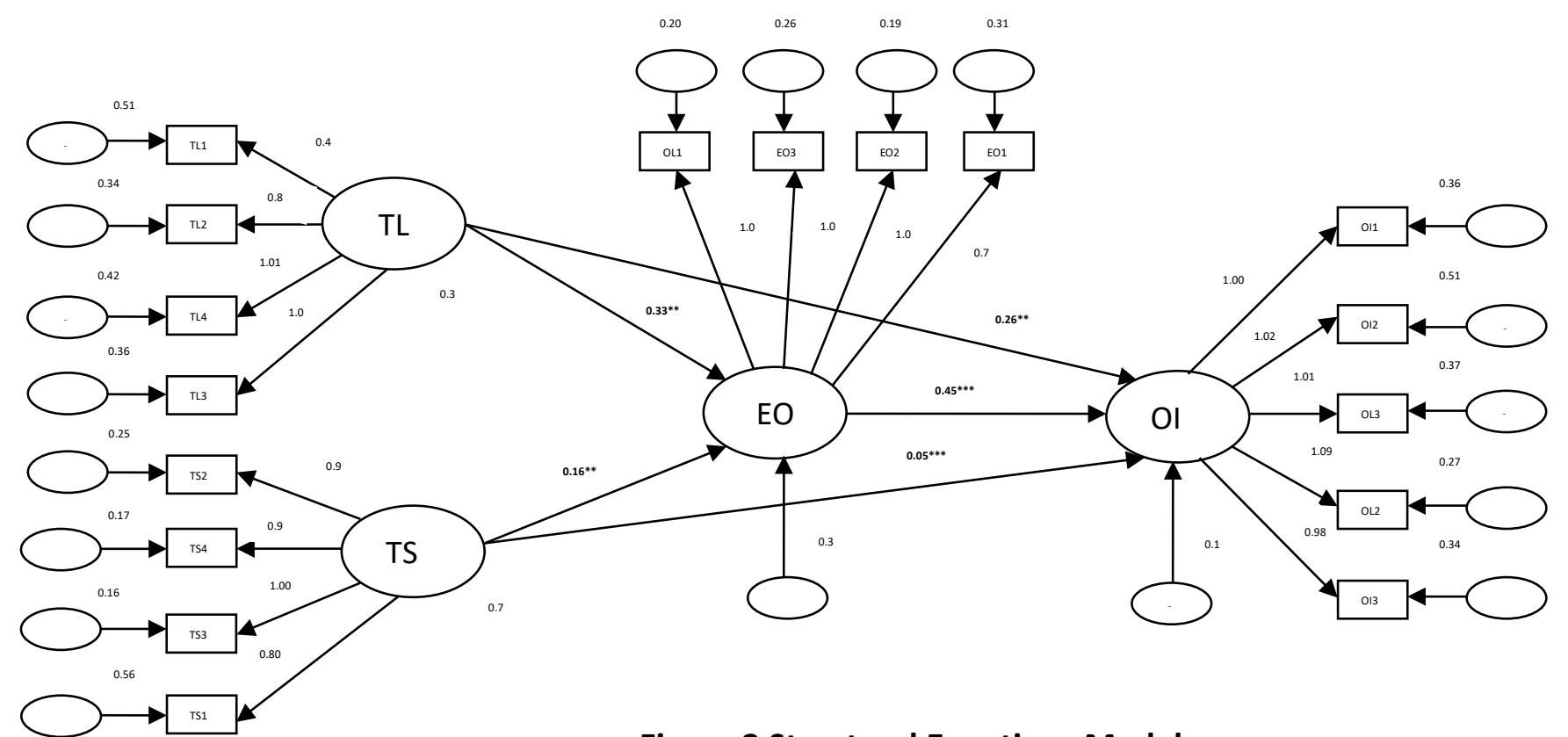

Figure 2 Structural Equations Model

The mediating effect of entrepreneurial orientation on the relationship between transformational leadership and transactional leadership. First, there is a positive relationship between transformational leadership and entrepreneurial orientation. Second, there is a positive relationship between 
transactional leadership and entrepreneurial orientation. And third, the direct effect of transformational leadership on organization innovation is significant. These conditions provide compelling evidence for the full mediating effect of entrepreneurial orientation on the relationship between transformational leadership and organization innovation. So, this mediation relationship represents a significant contribution to our understanding of positive influence of transformational leadership on organization innovation Results shown in Figure 2 provide support for the mediating effect of entrepreneurial orientation on the relationship between transactional leadership and organization innovation. First, there is a positive relationship between transactional leadership and organization innovation. Second, the direct effect of transactional leadership and organization innovation. These conditions provide compelling evidence for the full mediating effect of entrepreneurial orientation on the relationship between transactional leadership and organization innovation.

\section{Conclusions and Future research}

This study focuses on the mediating effect of entrepreneurial orientation on the relationship between transformational leadership, and organization innovation. In addition, the mediating effect of entrepreneurial orientation on the relationship between transactional leadership and organization innovation.

First, the research shows the mediating effect of entrepreneurial orientation on a beneficial relationship between transformational leadership, and organization innovation both first and second hand; this is achieved through the formulation of specific expertise which is concerned with education in order to minimize the cost of internal change (Lei et al., 1999; Slater and Narver, 1995). Thus, transformational leadership is highly associated with and promotes organizational learning (Senge, 1990; Swieringa and Wierdsma, 1992), making the resources that are needed to conquer any setbacks which may impede learning that might present themselves readily accessible (Wick and Leon, 1995). The aim of organization innovation is to lay the foundations for professional development in order to achieve the types of skills and competencies that enable organization innovation as a result of a sustainable advantage (Senge et al., 1994). Second, the research shows the mediating effect of entrepreneurial orientation on a positive relation between transactional leadership, and organizational innovation directly and indirectly through the construct. Thirdly, the study demonstrates empirically a positive relation between entrepreneurial orientation, and organizational innovation. Fourth, the study demonstrates empirically a positive relation between transactional leadership, entrepreneurial orientation, and organizational innovation. For example for innovation can follow at the individual, group, organization and industry levels. As new outputs, innovations may come from new knowledge as well as from the combination of existing knowledge to create innovations (Henderson and Clark, 1990) using combinative capabilities (Kogut and Zander, 1990). Radical and incremental innovations refer to high and low degrees of new knowledge (Dewar and Dutton, 1986) involving high and low degrees of organizational transformation. A learning organization is an innovative organization. Organizations' complexes of essential production and technology competences or resources and capacities sustain the sources for achieving sustainable competitive advantages. Each organization should analyze all of its production and technological resources, the resources that enable achievement of a better competitive position on the market. The organization should also develop specific capacities and essential competences to face the changes in production and technology in its environment. The innovative organization learns and knows how to make and keep itself competent. Through learning, the organization can change its behavior and thus renew and reinvent its technology and production to avoid falling into stagnation and to permit organization innovation. Different organizations will find 
themselves in different states of evolution in learning. Organizational learning prevents stagnation and encourages continuous innovation (Bessant and Buckingham, 1993; Glynn, 1996; Thomas et al., 2001).

Future research should examine whether the mediating and moderating influences of group processes such as cohesiveness, diversity, and conflict are the determinants of organization innovation rather than entrepreneurial orientation. The measure of organization innovation that this study develops and uses might be useful for studies in industries other than software development, or in industries which produce radical innovation. Studies in different countries can also use this measure in order to evaluate its external validity.

\section{Acknowledgement}

I am also grateful to many thanks Mahasarakham Business School, Mahasarakham University, Thailand for support of this research presentation.

\section{References}

[1] Aaker, David A., Kumar, V. and Day, George S. 2001, Marketing Research, New York: John Wiley and Sons.

[2] Alegre, J., Lapiedra, R., and Chiva, R.2006, A measurement scale for product innovation Performance. European Journal of Innovation Management, 9(4), pp. 333-346.

[3] Anderson, James C., Gerbing, David W.1988, Structural equation modeling in practice: A review and recommended two-step approach. Psychological Bulletin, 103(3), pp. 411-423.

[4] Antonakis, J., Avolio, B. J. and Sivasubramaniam, N.2003, Context and leadership: an examination of the nine-factor full-range leadership theory using the Multifactor Leadership Questionnaire, The Leadership Quarterly,(14), pp. 261-295.

[5] Avolio BJ, Bass BM, Jung DI.1999, Re-examining the components of transformational and transactional leadership using the Multifactor Leadership Questionnaire. Journal of Occupational and Organizational Psychology, 72 (4), pp. 441-63.

[6] Armstrong, J.S. and Overton, T.S.1977, Estimating Non-response Bias in Mail Surveys. Journal of Marketing Research, (3), 396.

[7] Baker, W. E., and Sinkula, J. M.1999, The synergistic effect of market orientation and leaning orientation on organizational performance. Journal of the Academy of Marketing Science, 27(4), pp. 411-427.

[8] Baker, W. E., and J. M. Sinkula. 2009, The Complementary Effects of Market Orientation and Entrepreneurial Orientation on Profitability in Small Business. Journal of Small Business Management, 47(4), pp. 443- 464.

[9] Barney, J.B.1991, Firm resources and sustained competitive advantage. Journal of Management, 17(1), pp. 99-120.

[10] Bass BM, Avolio BJ.1995, MLQ, Multifactor Leadership Questionnaire. 2nd ed. Redwood City, CA: Mind Garden.

[11] Bass, B. M.1985, Leadership and Performance Beyond Expectations, Free Press, NY.

[12] Bennis,W.G.1980, Leadership: A Beleaguered Species? In S. Ferguson and S.D. Ferguson, eds. Intercom: Readings in Organizational Communication. Rochelle Park, NJ: Hayden.

[13] Bennis,W.G.1984, Leadership: A Beleaguered Species?. In S. Ferguson and S.D. Ferguson, eds. Intercom: Readings in Organizational Communication. Rochelle Park, NJ: Hayden.

[14] Bessant J, Buckingham J.1993, Innovation and organizational learning: the case of Computeraided production management. British Journal of Management, 4(4), pp. 219-237.

[15] B. Kogut, and U. Zander. 1992, Knowledge of the firm, combinative capabilities, and the replication of technology. Organization Science. (3). pp. 383-397.

[16] Bou-Llusar, J. C., Escrig-Tena, A. B., Roca-Puig, V., and Beltra'n-Martı́n, I. 2009, An empirical assessment of the EFQM excellence model: Evaluation as a TQM frame-work relative to the MBNQA model. Journal of Operations Management, 27, pp.1-22.

[17] Bremer, I.2009, Common Factors between Swedish and Chinese Entrepreneurial Leadership Styles, 
Business. Intelligence Journal, 2(1), pp. 9-41.

[18] Brown, S. L., and Eisenhardt, K. M.1995, Product development: Past research, present findings, and future directions. Academy of Management Review, 20, pp. 343-378.

[19] Chelladurai. 2001, Leadership Preferences of Mentally Tough Athletes. Personality and Individual Differences, 47(4), pp. 326-330.

[20] Chiva, R., and Alegre, J.2009, Organizational learning capability and job satisfaction: An empirical assessment in the ceramic tile industry. British Journal of Management, 20(3), pp. 323-340.

[21] Chiesa, V., Coughlan, P., and Voss, C. A.1996, Development of a technological innovation audit, R\&D Management, 13, pp.105-136.

[22] Claes Fornell and David F. Larcker. 1981, Evaluating Structural Equation Models with Unobservable Variables and Measurement Error. Journal of Marketing Research, 18(1), pp. 39-50.

[23] Conger, J,A, and R,N, Kanugo.1989,Towards a Behavioral Theory of Charismatic Leadership in Organizational Settings. Academy of Management Review, (12), pp. 637-647.

[24] Cottrell and Sick. 2002, Real options and follower strategies: The loss of real option value to first-mover advantage. The Engineering Economist.

[25] Covin, J. G, Green, K. M., and Slevin, D. R. 2006, Strategic process effects on the entrepreneurialorientation-sales growth rate relationship. Entrepreneurship Theory and Prartice, 30(1), pp. 57-81.

[26] Covin, J.G. and Slevin, D.P.1989, A conceptual model of entrepreneurship as firm behavior. Entrepreneurship Theory and Practice, 16(1), pp. 7-24.

[27] Covin, J. G, and Slevin, D. P.1989, A Conceptual model of entrepreneurship as firm behavior. Entrepreneurship Theory and Practice, 16(1), pp. 7-25.

[28] Covin, J. G., and Slevin, D. P.1989, Strategic management of small firms in hostile and benign Environments. Strategic Management Journal, 10, pp. 75-87.

[29] Covin, J.G. and Wales, W.J. 2011, The measurement of entrepreneurial orientation Entrepreneurship Theory and Practice, 35, doi: 10.1111/j.1540 6520.2010.00432.x.

[30] Damanpour, F., and S. Gopalakrishnan. 2001, The Dynamics of the Adoption of Product and Process Innovations in Organizations. Journal of Management Studies, 38(1), pp. 45-65.

[31] Damanpour,F. 1991, Organizational innovation: A meta-analysis of effects of determinants and Moderators. Academy of Management Journal, 34, pp. 555- 590.

[32] David A. Garvin. 1993, Manufacturing Strategic Planning. California Management Review, (35) 4, pp. 85-106.

[33] Dess, G G, and Lumpkin, G. T.2005, The role of entrepreneurial orientation in stimulating effective corporate entrepreneurship. Academy of Management Executive, 19(1), pp. 147-156.

[34] Dess, G., Lumpkin, G. and McGee, J.1999, Linking Corporate Entrepreneurship to Strategy, Structure, and Process: Suggested Research Directions. Entrepreneurship: Theory and Practice, 23(3), pp. 85-102.

[35] Dibella, A. J., E. C. Nevis, and J. M. Gould.1996, Understanding Organizational Learning Capability. Journal of Management Studies, 33(3), pp. 361-379.

[36] Dickson Peter R.1996, The static and dynamic mechanics of competition: a comment on Hunt and Morgan's comparative advantage theory. J Mark, 60(4), pp. 102-106.

[37] D'Intino, R. S., Goldsby, M. G., Houghton, J. D. and Neck, C. P.2007, Self-leadership: A Process for Entrepreneurial Success. Journal of Leadership and Organizational Studies, 13, pp. 105120.

[38] Escriba' -Esteve, A., Sa'nchez-Peinado, E., and Sa'nchez-Peinado, M. L. 2008, Moderating influences of the firms strategic orientation-performance relationship. International Small Business Journal, 26(4), pp. 463-489.

[39] Gatignon et al., 2002, A structural approach to assessing innovation: Construct development of innovation locus, type, and characteristics. Management Science, 48 (9), pp. 1103-1122.

[40] Geert Hofstede. 2001, Culture's Consequences: Comparing Values, Behaviors, Institutions, and Organizations Across Nations. Second Edition, Thousand Oaks CA: Sage Publications.

[41] Geert Hofstede, Gert Jan Hofstede and Michael Minkov. 2010, Cultures and Organizations: Software of the Mind. Revised and Expanded 3rd Edition. McGraw-Hill. 
[42] Glynn MA.1996, Innovative genius: a framework for relating individual and organizational intelligences to innovation. Academy of Management Review, 21, pp. 1081-1111.

[43] Green, K. M., Covin, J. G., and Slevin, D. P. 2008, Exploring the relationship between strategic reactiveness and entrepreneurial orientation: The role of structure-style fit. Journal of Business Venturing, 23, pp.356-380.

[44] Hair, H. F., Anderson, R. E., Tatham, R. L., and Black, W. C.1998, Multivariate data analysis, London: Prentice Hall.

[45] Hitt, M. A., Biermant, L., Shimizu, K., and Kochhar, R.,2001, Direct and moderating effects of human capital on strategy and performance in professional service firms: A resource-based perspective. Academy of Management Journal, 44(1), pp.13-28.

[46] Hornsby, J.S., Naffziger, D.W., Kuratko, D.F., and Montagno, R.V., 1993, An interactive model of the corporate entrepreneurship process. Entrepreneurship Theory and Practice, 17(2), pp. 29-37.

[47] Huber George P.1991, Organizational learning the contributing processes and the literatures. Organ Sci, 2(1), pp. 88-115.

[48] Hult, G. Tomas M. and O.C. Ferrell. 1997, Global Organizational Learning Capacity in Purchasing: Construct and Measurement. Journal of Business Research, 40(2), pp. 97-112.

[49] Hult, G.T.M. and Ketchen, D.J., Jr.2001, Does market orientation matter? A test of the relationship between positional advantage and performance. Strategic Management Journal, 22(9), pp. 899-906.

[50] INE. 2008, Encuesta sobre Innovacio'n Tecnolo'gica en las Empresas, Madrid: INE.

[51] Kotter, J. P.1996, Leading Change. Cambridge: Harvard Business School Press.

[52] Koufteros X, Babbar S, Kaighobadi M. 2009, A paradigm for examining second-order factor models employing structural equation modeling. International Journal of Production Economics, 120, pp. 63352.

[53] Lei D, Slocum JW, Pitts RA. 1999, Designing organizations for competitive advantage: the power of unlearning and learning. Organizational Dynamics, 28(3), pp. 24-38.

[54] Limsila, K. O gunlana. S.O. 2007, Performance and leadership outcome correlates of leadership styles and subordinate commitment. Engineering, Construction and Architectural Management, 15(2), pp. 164-184.

[55] Lumpkin, G T., and Dess, G. G. 1996, Clarifying the entrepreneurial orientation construct and linking it to performance. Academy of Management Review, 21(1), pp. 135-172.

[56] Lyon, D. W., Lumpkin, G. T., and Dess, G. G.2000, Enhancing entrepreneurial orientation research: Operationalizing and measuring a key strategic decision making process. Journal of Management, 26, pp. $1055-1084$

[57] Ma, H. and Tan, J. 2006, Key components and implications of entrepreneurship:A 4-P framework. Journal of Business Venturing, 21(5), pp. 704-725.

[58] Michael E. Porter. 1980, Competitive Strategy, The Free Press, New York, 2(1) pp. 93-95.

[59] Neter, John V., William, Wasserman, and Michael, H. Kutner., 1985, Applied Linear Statistical Models: Regression Analysis of Variance and Experimental Design, 2nd Edition, Homewood: Richard D. lewin.

[60] Nunnally, J.C. and Bernstein, I.H. 1994, Psychometric Theory (3rd Edition). McGraw-Hill Series in Psychology, McGraw-Hill, Inc., New York: NY, (21) pp.451-468.

[61] OECD. 2005, The measurement of scientific and technological activities. Proposed guidelines for collecting and interpreting technological data, In Oslo Manual. Paris: OECD.

[62] Philip M. Podsakoff, Scott B. MacKenzie, and Jeong-Yeon Lee, Nathan P. Podsakoff. 2003, Common Method Biases in Behavioral Research: A Critical Review of the Literature and Recommended Remedies. Journal of Applied Psychology, 88 (5), pp. 879-903.

[63] Rauch, A., Wiklund, J., Lumpkin, G.T., and Frese, M. 2009, Entrepreneurial orientation and business performance: An assessment of past research and suggestions for the future. Entrepreneurship Theory and Practice, 33(3), pp. 761-787.

[64] Renko, M., A. Carsrud, and M. Brännback. 2009, The Effect of a Market Orientation, Entrepreneurial Orientation, and Technological Capability on Innovativeness: A Study of Young Biotechnology Ventures in the United States and in Scandinavia. Journal of Small Business Management, 43(3), pp. 331-369.

[65] R.D. Dewar, and J.E. Dutton. 1986, The adoption of radical and incremental innovations: an empirical analysis. Management Science, (32)11, pp. 1422-1433. 
[66] R.M. Henderson, and K.C. Clark. 1990, Architectural innovation: the reconfiguration of existing product technologies and the failure of established firms. Administrative Science, 35, pp. 9-30.

[67] Rosenbach, W, M, Sashkin, and F, Harburg. 1996, The Leadership Profile. Seabrook, MD: Ducochon Press.

[68] Sadler-Smith, E., Y. Hampson, I. Chaston, and B. Badger. 2003,Managerial Behavior, Entrepreneurial Style, and Small Firm Performance. Journal of Small Business Management, 41(1), pp. 47-68.

[69] Samad S.2011, The contribution of quality management system and quality product on organizational performance in Malaysian logistics companies. Euro J Soc Sci, (25), pp. 66-76.

[70] Sashkin, M. 1990, Strategic Leadership Competencies, In R,L, Phillips and J,G, Hunt, eds,. Strategic Leadership: A Multi-Organizational Perspective. Westport, CT: Quorum.

[71] Sashkin, M., and WE, Rosenbach. 1998, A New Vision of Leadership, In WE, Rosebach and R,L, Taylor, eds,. Contemporary Issues in Leadership, 4th ed. Boulder, CO: Westview Press.

[72] Senge PM. The fifth discipline.1990, New York: Doubleday Publ.

[73] Senge P, Roberts C, Ross RB, Smith BJ, Kleiner A.1994, The fifth discipline fieldbook. New York: Doubleday Publ.

[74] Shastri, R.K.; Shashi Mishra, K. and Sinha, A.2010,Charismatic leadership and organizational commitment: An Indian perspective. African Journal of Business Management, 4(10), pp. 1946-1953.

[75] Slater SF, Narver JC.1995, Market orientation and the learning organization. Journal of Marketing, 5(3), pp.63-74.

[76] Swieringa J, Wierdsma A. Becoming a learning organization.1992, MA: Addison-Wesley.

[77] Tellis GJ, Prabhu JC., Chandy RK. 2009, Radical innovation across nations: The pre-eminence of corporate culture. J Mark, (73), pp. 3-23.

[78] Thomas JB, Sussman SW, Henderson JC. 2001, Understanding: 'strategic learning': linking organizational learning, knowledge management, and sensemaking. Organization Science, (12), pp. 331-45.

[79] Tippins, M. J., and Sohi, R. S.2003, IT competency and firm performance: Is organizational learning a missing link? Strategic Management Journal, 24, pp. 745-761.

[80] Utterback, J., and W. Abernathy.1975, A Dynamic Model of Product and Process Innovation, Omega, 3, pp. 639-656.

[81] Vohora, A., Wright, M., and Lockett, A. 2004, Critical junctures in the development of university high tech spin-out companies. Ae^earc/î PoZ/cy, 33(1), pp.147-175.

[82] Wang, C. L. 2008, Entrepreneurial Orientation, Learning Orientation, and Firm Performance, Entrepreneurship: Theory and Practice, 32, pp. 635-657.

[83] Weerawardena, J., O'Cass, A., and Julian, C. 2006, Does industry matter? Examining the role of industry structure and organizational learning in innovation and brand performance. Journal of Business Research, 59 (1), pp. 37-45.

[84] Wheelwright, S. C., and Clark, K. B. 1992, Revolutionizing product development - quantum leaps in speed, efficiency, and quality. New York: The Free Press.

[85] Wick and Leon. 1995, The Relationship among Transformational Leadership, Organizational Learning, and Organizational Innovation : A case study in Asian manufacturing food industry. Asian Journal of Empirical Research.

[86] Wiklund.1999, The Sustainability of the Entrepreneurial Orientation-Performance Relationship, Entrepreneurship Theory and Practice, 24, pp. 37-48.

[87] Wiklund, J. 1998, Small firm growth and performance: Entrepreneurship and beyond. Jönköping, Sweden: Jönköping International Business School.

[88] Wiklund, J. and Shepherd, D. 2003, Knowledge-based resources, entrepreneurial orientation, and the performance of small and medium-sized businesses. Strategic Management Journal, 24(13), pp. 13071314.

[89] Wilkens, U., Menzel, D., and Pawlowsky, P. 2004, Inside the black-box: Analyzing the generation of core competencies and dynamic capabilities by exploring collective minds. Management Review, 15(1),pp. 826.

[90] Wieland, J., \& Shepherd, D. 2005, Entrepreneurial orientation and small business performance: A configurational approach. Journal of Business Venturing, 20(1), pp. 71- 91. 
[91] Yammarino, F. J. and Dubinsky, A. J. 1994, Transformational Leadership Theory: Using Levels of Analysis to Determine Boundary Condition. Personnel Psychology, (47), pp. 787-811.

[92] Yukl, G.A. 1998, Leadership in organizations (4th ed.). Upper Saddle River, NJ: Prentice-Hall, Inc.

[93] Zahra, S. A., A. P. Nielsen, and W. C. Bogner. 1999, Corporate Entrepreneurship, Knowledge, and Competence Development, Entrepreneurship Theory and Practice, 23, pp. 169-189

[94] Zahra, S.A. and Covin, J.G. 1995, Contextual influences on the corporate entrepreneurship performance relationship: A longitudinal analysis. Journal of Business Venturing, 10(3), pp. 43-58.

[95] Zhou, Kevin Z. and Li, Caroline B. 2007, How does Strategic Orientations Influence matter in Chinese firms?. Asia Pacific Journal of Management, 24, pp. 447- 466.

[96] Zhou, K.Z., Yim, C.K., and Tse, D.K. 2005, The effects of strategic orientations on technology- and marketbased breakthrough innovations. Journal of Marketing, 69(2), pp. 42-60.

[97] Zahra, S. A., Sapienza, H. J., and Davidsson, P. 2006, Entrepreneurship and dynamic capabilities: A review, model and research agenda. Journal of Management Studies, 43(4), pp. 917-955.

[98] Zott, C. 2003, Dynamic Capabilities and the Emergence of Intra industry Differential Firm Performance: Insights from a Simulation Study, Strategic Management Journal, 24, pp. 97-125. 